International Journal of Economics, Business and Accounting Research (IJEBAR)

Peer Reviewed - International Journal

Vol-4, Issue-3, 2019 (IJEBAR)

E-ISSN: 2614-1280 P-ISSN 2622-4771

https://jurnal.stie-aas.ac.id/index.php/IJEBAR

\title{
DETERMINING FACTOR FOR MALAYSIAN MONEY DEMAND FUNCTION
}

\author{
Muhammad Ahmad Mazher ${ }^{1}$, Prof. Dr. Jauhari Dahlan ${ }^{2}$ \\ Business School, University Kuala Lumpur, Malaysia ${ }^{1,2}$ \\ E-mail: muhammad.mazher@s.unik.edu.my
}

\begin{abstract}
The reason for our study was to determine the factors that influence the role of money demand in the Malaysian economy. We implicit various economic factors comprise real CPI, real interest rate, financial innovation, and real GDP and analyzed through implying ARDL Bound test for short-run and the long-run period over 1970-2018 time-series data. Based on empirical results, we revealed that over the short-run period, financial innovation having positive and significant while real GDP has a negative and significant relationship with real money demand function in Malaysia. The official real exchange rate has a positive and significant relationship with real money demand, with an increase of one unit in the real exchange rate, increasing the money demand function by 0.97 in the long term. More, negative and significant relationships revealed among real GDP and real money demand function which direct that by increase 1\% change in real GDP direct to decrease in real money demand by 0.6395 in the Malaysian economy and finally real money demand predicted 13.0796 when all independent variable is zero in the Malaysian economy.
\end{abstract}

Keywords: $\quad$ Rea money demand, Real CPI, Real Interest rate, Financial Innovation, RGDP

\section{Introduction}

During the contemporary eras, through intention to establishing and analysis to the accomplishment of money demand function $\left(\mathrm{M}_{\mathrm{d}}\right)$ steadiness, the number of studies steered which intended research scholars and academics from developed and developing states for exploration and policy establishment concerned with money demand function. Exclusively, the consequence and importance in regards to inference particularly apprehensive through policy formation with assuring that monetary policies can be directed effectively argued by Arango and Nadiri (1981), Bahmani-Oskooee and Tanku (2006), Hoffman et al. (1995). The importance of money demand function explicitly for the federal bank because it examines the money supply (Ms) growth rate objectives during the medium-term and also observes total liquidity through interest rate and manipulation in money reserve described by Treichel (1997). According to the researcher, to attain stable money demand function there is need of good monetary policy. Conversely, the unstable money demand function conclude significant for financial reforms and rise in new financial assets appearance that direct to incompatibility among targets of monetary growth, real economic growth, growth of money supply as well as wrongly or inaccurately besets monetary aggregates to imitate an economy's total liquidity.

The money held by the private sector is called "monetary demand/demand for money." The two mainfunctions of money that create the source of detention include functions such as "means of exchange" and "store value". Bitrus (2011) described the demand for money as a means of exchange. This shows that while trade is facilitated, money produces prosperity as a function of accumulated value. Therefore, the concept of money demand function plays a dynamic and important role in monetary economics. Sichei and Kamau (2012) conferred the significance of 
International Journal of Economics, Business and Accounting Research (IJEBAR)

Peer Reviewed - International Journal

Vol-4, Issue-3, 2019 (IJEBAR)

E-ISSN: 2614-1280 P-ISSN 2622-4771

https://jurnal.stie-aas.ac.id/index.php/IJEBAR

demand for money variables for academic scholars and refer to the cause of importance that is very much concerned with the monetary policy framework compiling variable. The high attention is given by monetary policy towards the demand for money concepts because of its virtuous controlling with led to effective monetary policy implications and ultimately revealed a positive and significant impact on the economy by this process. Particularly $\mathrm{M}_{\mathrm{d}}$ function is essential to the realization process of physical money market awareness while executing real monetary policy by any country. A reliable optimal monetary policy never described by economists while the important money demand function absence in their estimates. A capable money interrelated contextual plays robust role in any economy's long-run economic potentials and projections undertakes roles comprise, delivers information regarding investment, allows mobilization and merging savings and capital provision, confirms monitoring about investment and corporate governance proceeding to debt capital, ease trading, broadening and management hazard and lastly but not least comfort exchange of goods \& services. Friedman (1956) described that money demand work confirms a static a long-time ago run balance interaction between money adjusts, genuine pay and open door cost of keeping genuine adjusts which considered work demand for money. Since the presentation of the co-integration investigation through Engle and Granger (1987), this relationship has acquired a boosting consideration, especially the solidness problem of financial experts who have warred about changes in the demand for money, on account that demand stuns can impact yield changeability and have recommendations for fiscal approach; for instance, Kontolemis (2002) communicates, soundness of considering a long term in the past run money demand for paintings is an extensive factor for the intention that a long time ago run development paces of fiscal factors.

Real money demand can be divided theoretically into three types of transaction, precautionary, and speculative demands. In theory, the demand for transactions shows a positive association with income and a negative linking with interest rates. The precautionary demand occasioned a positive proportion to income, and negative ratio resulted in speculation and interest rates. Subsequently, real-world practices showed the value of credit does matter for developing economies, meanwhile in developing economies, the transaction through M2 (broad money) impartially frequently takes place. For smooth and development related activities, government, business owner, and investor always used credit for lending facilities. Financial institutions including banking sectors create money through loaning or providing credit to individuals and organizations. Nevertheless, during the boom and when returns on investments are high, this situation leads to enhancement in lending and borrowing activities comparative to lower cost of credit. Contrariwise, during the economic crises (inflations or deflation), the financial institutions demotivate the borrowing activities by charging a high rate of interest. Hence, Yu and Gan (2009) exposed that when the cost of borrowing rises, demand for money decreases in any economy.

According to Wihardja (2013), as the national blueprint, the Malaysian economy has incorporated the ASEAN. Resultantly, the financial sector transformed into additionally de-regulated as well as market-oriented which leads to international integration and more liberalization described by Bank Negara Malaysia (2011). Moreover, Noman et al. (2017) described that comparative to four ASEAN economies, the cost-to-income formation of banking operations in Malaysia by various financial institutions and banks led to more efficiency. Thus, financial reforms make the cause of the effect of monetary targeting performance. Various influential studies comprise GHaffar et al. (1987); Rahim (1986); Semudram (1981) discussed on demand for money related topics in the Malaysian economy. These researches implied partial adjustment description commonly rather than analysing the series properties and co-integration methods. Tseng and Corker (1991) analysed on various problems that comprise financial liberalization impact through concentrating on instability causes over the 1980s era. More, the researchers studied whether exchange rate factors could be utilized being a determinant of demand for money function to measure stability motive in the long-run. 
International Journal of Economics, Business and Accounting Research (IJEBAR)

Peer Reviewed - International Journal

Vol-4, Issue-3, 2019 (IJEBAR)

E-ISSN: 2614-1280 P-ISSN 2622-4771

https://jurnal.stie-aas.ac.id/index.php/IJEBAR

Finally, based on several searches of empirical and theoretical literature, we have proposed broad money (M2) as a proxy for money called $\mathrm{M}_{\mathrm{d}}, \mathrm{CPI}$, real interest rate and financial innovation as proxy of domestic credit to private sector by banks as \% of GDP and real GDP.

\section{Literature Review}

\subsection{Theoretical Literature Review}

An item, element, or thing having worth and legal tender to payback domestic and international debt obligations, utilized for investment purposes, means in exchange in finance, utilizing for financial records, etc. is considered as money. It always induced by the government of the country under the legal tender. Bank money and legal tender are two basics sources of money creation in any economy. The value or worth in the form of money of goods is called its nominal value. Money values in various years of somewhat are called nominal values in economic theory. More specifically, the effect of the nominal value of the time series is recognized as real value to obtain a critical image of economic trends, eliminating changes in price levels.

While real values may be defined as the value or worth in form of some other goods, services, and the basket of goods, etc. Real values regulate for transformation or differences in the price level in those years or more simply the values adjusted for inflation are known as real values. For the real price of goods and services, there is another term known as 'real price'. When an individual talk about the 'relative price' of laptop has dropped during recent years, it direct to the price of laptop relative to or restrained in term of other goods \& services like LCD, Motorbike or car, etc. has deteriorated. During inflation, if nominal prices increase, relative prices of individual goods $\&$ services can desire. The purchasing power of money is called real money. Due to inflation, there are frequent variations in the value of real money. A right decision can be made by various companies if they estimate their performance in real money term meanwhile considered capital opportunity cost and inflation. State of the economy showed by money supply estimated in terms of nominal in any country. The financial innovation, real GDP, interest rate and price level may be the cause of money quantity hold by individuals. Bara and Mudzingiri (2016) identified two indicators of financial innovation, which include a broader monetary relationship, narrow money (M2 / M1) and a banking sector with a private sector (interest rate) to GDP. As a percentage of GDP)

\section{Real Money Demand (M/P)}

The relationship between money quantity and price level is the concept of real demand for money. The amount may include a nominal amount (M1) or a narrow amount (M2). In a monetary economy, the own desire for financial assets in the form of money is called real demand for money. It may comprise cash and bank deposits (excluding investment) and narrowly it is a notion as M1 (Directly spendable assets - Checkable deposits and money in circulation includes in M1 category) and in the broad sense as M2 (It comprise M1 + Saving Deposits $(<\$ 100 \mathrm{~K})+$ Money market mutual funds) and M3 (It comprise M2 + Large bank deposits).

\section{The Price Level (Consumer Price Index - CPI)}

Monetary Set (M1) or nominal money is measured in dollars and the CPI and the amount of money, also called money demand, are proportional. For instance, in the case of $10 \%$ in prices, individuals will hold more than $10 \%$ of the money for purchasing the same goods bundle. i.e., if an individual purchases the cup of coffee with some sacks at $\$ 10$ earlier, now he will need more $\$ 1$ to hold within for purchasing the same. "Real money" measured in dollars. What it will buy, does it estimate? The quantity of real $\mathrm{M}_{\mathrm{d}}$ remnants self-determining of the price level.

\section{The Interest Rate}

The rate of interest which a private could be earned on assets holds as an alternate of cash/money referred as opportunity cost of holding money. It has an inverse relationship 
International Journal of Economics, Business and Accounting Research (IJEBAR)

Peer Reviewed - International Journal

Vol-4, Issue-3, 2019 (IJEBAR)

E-ISSN: 2614-1280 P-ISSN 2622-4771

https://jurnal.stie-aas.ac.id/index.php/IJEBAR

between opportunity cost and $\mathrm{Md}$ or in other words when the interest rate, which is the cost of opportunity, is high, it will lead to less demand for money $\left(\mathrm{M}_{\mathrm{d}}\right)$.

\section{Real GDP}

Planned spending direct to money holding. In any economy, the quantity of $\mathrm{M}_{\mathrm{d}}$ be contingent toward real GDP generally. Hence, high level of spending because of high income, individuals hold abundant quantity of money with them for higher-spending volume.

\section{Financial Innovation}

Quantity of money seized gets affected by the transformation in technologies. It involves a day-to-day interest in checking deposits, automatic transfers between checking and saving deposits, ATM, credit cards. Generally, the demand for money $\left(\mathrm{M}_{\mathrm{d}}\right)$ being compact in the above innovations.

\section{Money Demand Curve}

The relationship between interest rates and real money demand $\left(\mathrm{M}_{\mathrm{d}}\right)$ is illustrated by the moneydemand curves.
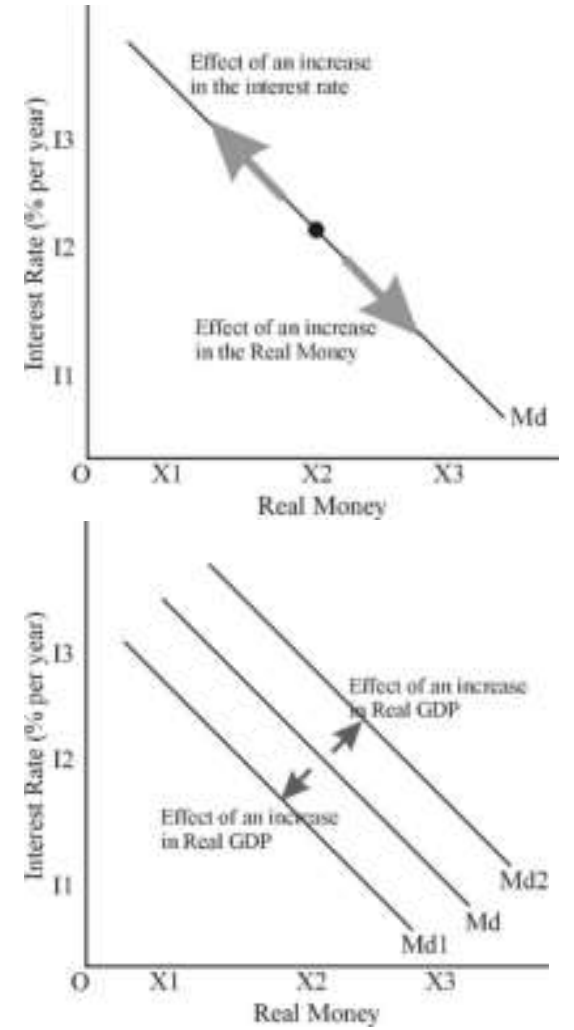

Due to variations in real GDP and financial innovations, fluctuations occurrence in $\mathrm{M}_{\mathrm{d}}$ and resultantly moves occurred in the real $\mathrm{M}_{\mathrm{d}}$ curve. Three crucial motives comprise transactional, precautionary, and asset demands to keep money by individuals with them. Term 'transaction demand' recognized and familiarized by classical economists and Keynes (1936) trailed by the 'theory of liquidity preference' presented by classical school of thought. It can be clarified as, the money holding for the exchange to make payment. It contains money stock. The individual keeps with them for day-to-day anticipated expenditures. The negative relationship exposed between transactional demand and interest rate by Baumol (1952) and Tobin (1956). Individuals minimize their money holding for transaction motives once rate of interest deteriorate because of opportunity of money holding intensify. Precautionary demands can be explained as the money holding for impulsive or emergency expenses and these 
International Journal of Economics, Business and Accounting Research (IJEBAR)

Peer Reviewed - International Journal

Vol-4, Issue-3, 2019 (IJEBAR)

E-ISSN: 2614-1280 P-ISSN 2622-4771

https://jurnal.stie-aas.ac.id/index.php/IJEBAR

transactions are proportional to income. If incomes increase, these balances also rise to attain the same protection level of safety. Therefore, the negative relationship between the precautionary demand and the interest rate is confirmed.

Keynes (1936) described that an individual always having faith in normal interest rate value. If the interest rate remains at a low level, it led to prediction to increase in the interest rate and bond price by the peoples. Individuals suffer a capital loss if and only if, there is a decrease in bond price compensate the interest gain. Zero return of money outstrips bonds negative returns as of demand for money by an individual's. In the case of the high current rate of interest, individuals forecast price rises for bonds and interest rate reduction. If a fall in interest rate compensates by the rise in bond price, individuals gain capital. Resultantly, people's demand for money minimum because of return on money surpasses to zero, and finally, the negative relationship exposed between speculative or asset demand and interest rate. The amount of money demanded transaction motives remains constant at a given level of income. The holding money opportunity cost makes the reason for the determination of the precautionary or asset demand. The following diagram showing the demand for money curve.

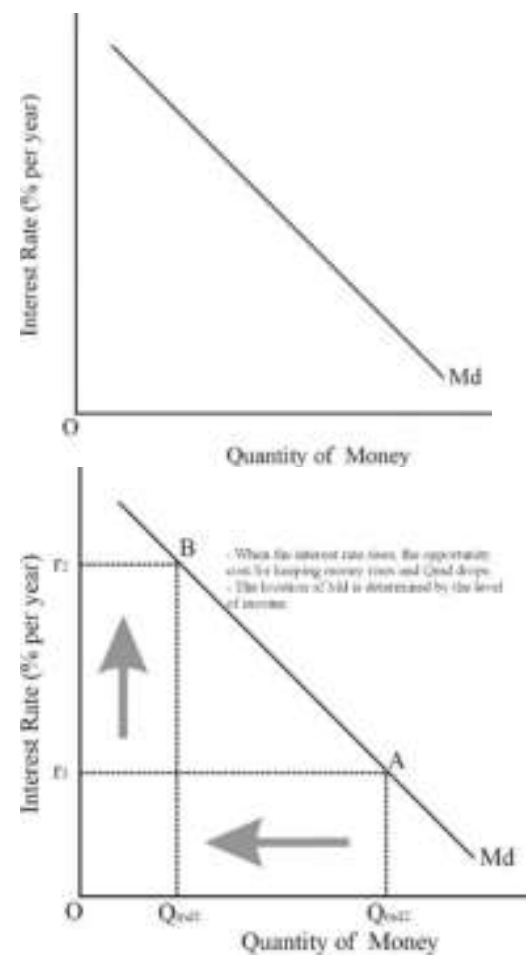

\section{Determination of Interest rate in Money Market}

The rate of interest can be concluded through the contact between money demands $\left(\mathrm{M}_{\mathrm{d}}\right)$ and money supply $\left(\mathrm{M}_{\mathrm{s}}\right)$. The point of interaction confirms the rate of interest. Keynes in his 'theory of liquidity preference' described that modifications in interest rate led to $M_{d}$ and $M_{s}$ in steadiness situation. Finally, the point of interaction between $\mathrm{M}_{\mathrm{d}}$ and $\mathrm{M}_{\mathrm{s}}$ also confirms the money market equilibrium.

At any specific time, the Fed can affect the money supply $\left(M_{s}\right)$ meanwhile the quantity of real money supply is a constant (considered constant because it cannot increase or decrease immediately) or a fixed amount.

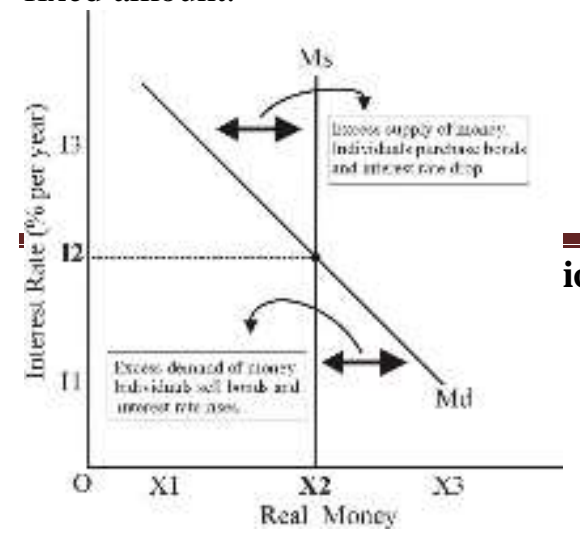


There may be various reasons for changing the interest rate comprise Fed initiates to anxiety inflation, discouraging borrowing through increase interest rate, selling securities in the open market by Fed, through dropping bank's reserves, by issuing fewer new loans, and decreasing the money supply.

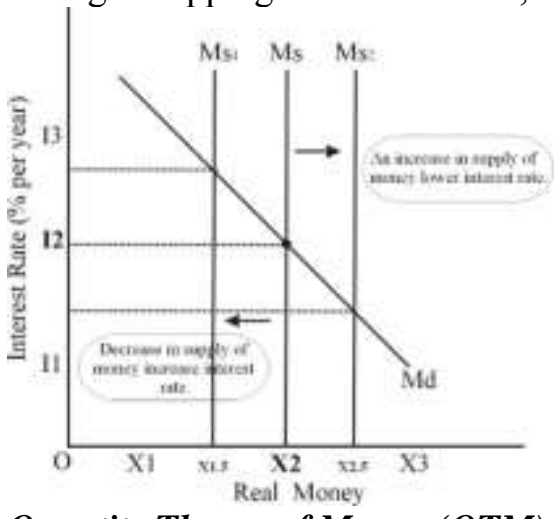

Quantity Theory of Money (QTM)

During the long-run, prices increased by increases in monetary growth nonetheless might be little or no effect on productivity explained by Milton Friedman (1956). He argued that under the short-run, production and employment level increased due to rise in growth of $\mathrm{M}_{\mathrm{s}}$, through a decrease in money supply growth, employment and production dropped. According to Milton Friedman, it is always and even everywhere monetary miracles. Hence, price level $(\mathrm{P})$ determined by available quantity of money $\left(\mathrm{Q}_{\mathrm{m}}\right)$, and likewise, inflation rate firm through the $\mathrm{Q}_{\mathrm{m}}$ available.

Formation of surplus supply of money (Ms) is the upshot of an instant consequence of a rise in Ms. It must be remembered that increase in money held by the individuals does not mean that it is the result of an increase in Ms. It works in a process as, by lessening interest rate, money demand $\left(\mathbf{M}_{\mathrm{d}}\right)$ increases. Individuals attempt to release this excess Ms in various customs comprise buying goods and services with excess funds and/or to make loans to others. More, assume that credits amounts can be exploited for purchasing goods and services since the supply of goods had not changed. Finally, prices move upwards because the demand for goods \& services increases in the economy. How many times a distinctive dollar bill employed for compensation of newly-produced goods and services in a year, is another interpretation of QTM.

\subsection{Empirical Literature Review}

According to Kombo and Nyangoro (2019), his research analysis founds the real money-demand function for Kenya and examine its steadiness in the attention of quick development of financial innovations and efficiency of monetary policy. Based on quarterly data empirical analysis, through implying Engle-Granger, VECM researchers establish co-integration and revealed structural breaks in Kenya's real money demand function. The outcomes reveal that interest rate does not distress demand for real money balances, whereas local domestic asset holders encourage to hold interest in earning financial assets as a substitute for cash balance during the short-run period. Researchers suggest the usage of substitute monetary policy context which is not based on money supply aggregates, like nominal GDP targeting alone or in grouping with others to attain goals of monetary policy. Narayan et al. (2009) Estimate the money demand function of SAC group (South Asian countries) 
International Journal of Economics, Business and Accounting Research (IJEBAR)

Peer Reviewed - International Journal

Vol-4, Issue-3, 2019 (IJEBAR)

E-ISSN: 2614-1280 P-ISSN 2622-4771

https://jurnal.stie-aas.ac.id/index.php/IJEBAR

including Bangladesh, India, Pakistan, Sri Lanka and Nepal from 1974 to 2002. Researchers exposed factors influence real income, real exchange rates, and domestic and shortterm foreign currency interest rates. Taken together, these signs give a clear indication of the longterm elasticity of a statistically significant relationship between money demand and its drivers.

Ahmad and Munirs (2000), studied the phenomena regarding money-demand in Pakistan from 1972 to 1996. The outcome leads that the inflation rate instead of interest rate that might be contacted in regards to steady money-demand. More, a lot of adjustments in money-demand are implanting by monetary establishments to track money market steadiness.

According to Anwar and Asghar (2012), defeating the financial and economic variation is the strategic and fundamental task for monetary policy competency, and whatever variables stimulus the demand for money is the sound for effervescent information. Through involving real income, inflation, exchange rate, and real demand for money, an analysis conducted by applying the ARDL technique, a researcher revealed that M2 monetary aggregates co-integrated with their influential factors in terms of the long-run association seems by all accounts look like steady. The investigation recommends that monetary establishments and policymakers must concentrate just on long-run adjustment policy in Pakistan. Darrat (1985) discussed a central role of demand for money function is various economic theories regarding aggregate economic activity particularly for establishing and implementation any monetary policy. The researcher examines the developing economy of Kenya and evident the empirical outcome that conventional money definition which is based on narrow and broad, and theoretical model fit on Kenya's economy very well. More, outcomes direct that some of the measures concerning foreign interest rates play a significant key role in Kenya's money demand function. Achsani (2010) described that monetary policy always admitted the most important element being predicted steady money demand function while monetary aggregates always having significant intervention on output, interest rate, and level of prices. The researcher implied VECM and ARDL econometric techniques and estimation outcomes signpost that demand for real M2 money amassed was co-integrated with interest rate and real income in Indonesia for the period of 1990Q1 to 2008Q3. Real money demand revealed a positive relationship with real income for short and long-run period and interest rate exposed negative impression on M2 for long-run period.

sSkrabic and Tomic-Plazibat (2009) studied the demand for real money in Croatia, time series analysis. Using Johansen's co-integration test, VAR and VECM techniques, the researchers established the uniqueness of the descriptive variable. The results show a slow rate of adjustment to eliminate inequality over the long term. Although interest rates have risen significantly in the short term, industrial production and real exchange rates represent the demand for different types of money in the long run. Chen (1997) initiated a long-term money demand through M0 and M2, and the use of annual time series data from China from 1951 to 1991. In addition, it also responds to flexibility. Real money demand applies to M0 and M2 between 1.4 and 1.5 and 1.8 and 1.9, respectively. If Chinese inflation is less than $10 \%$, the target $\mathrm{M} 2$ growth rate should not exceed $28 \%$ to $29 \%$. Choudhry (1995) concluded that the three countries, including Argentina, Israel and Mexico, support Johansen's steady co-integration long-term demand for finance function through joint integration. This happened only when the exchange rate (devaluation of the currency) was assumed in the money demand function.

\section{Research Method}

An imperative concern comes across by policymakers in developed and developing economies predictable as stable money demand function. Several factors may include money demand function determination. It is very crucial to select the variable while the construction of a model for money demand function.

Proxies for financial innovation comprise M2/M1 (ratio between broad money to narrow money) and GBCP/GDP (credit growth in banking to private sectors as a proportion of GDP) assumed by Bara 
International Journal of Economics, Business and Accounting Research (IJEBAR)

Peer Reviewed - International Journal

Vol-4, Issue-3, 2019 (IJEBAR)

E-ISSN: 2614-1280 P-ISSN 2622-4771

https://jurnal.stie-aas.ac.id/index.php/IJEBAR

and Mudzingiri (2016). Hence, $\mathrm{M}_{\mathrm{d}}$ depends upon interest rate, real GDP, financial innovation, and price level. Likewise, considering currency alternative into account, numerous researchers analysed demand for money $\left(\mathrm{M}_{\mathrm{d}}\right)$ for developing economies and include variables most of the time named as 'exchange rate' when they defined their $M_{d}$ functions. Mundell (1963) insertion this variable $s$ standard for money demand function initially.

$$
\text { Real } M_{d}=\beta_{0}+\beta_{1} \text { OEXR }+\beta_{2} \text { RGDP }+\beta_{3} \text { FI }+\beta_{4} \text { RIR }+\varepsilon
$$

Here, Real $M_{d}$ referred as real money demand which is imitative over the ratio between broad money (M2) to real consumer price index (measured in P), OEXR as official exchange rate, RGDP as a real gross domestic product, FI as financial innovations (domestic credit to private sector by banks $\%$ of GDP), and RIR as the real interest rate (lending interest rate adjusted for inflation as measured through GDP deflator).

Our data set comprises yearly time series data from WDI (World Bank), over the period 1970-2018 for the Malaysian economy.

\section{Results and Discussion}

\subsection{Unit-root}

The motive to conduct the unit-root test was to confirm the integration-related properties of all variables. We involve the Phillip-Perron method to conduct the unit-root test which revealed the following stationary levels.

\begin{tabular}{|l|c|c|l|}
\hline \multicolumn{4}{|c|}{ Unit-root Results (Phillips-Perron Method) } \\
\hline \multirow{2}{*}{ Variable(s) } & \multicolumn{2}{|c|}{ Probability } & \multirow{2}{*}{ Stationary Remarks } \\
\cline { 2 - 4 } & $\mathrm{I}(0)$ & $\mathrm{I}(1)$ & \\
\hline LFI & 0.0605 & 0.0000 & Stationary at $1^{\text {st }}$ level \\
\hline LM2/LRCPI & 0.0000 & - & Stationary at level \\
\hline LOEXR & 0.8271 & 0.0002 & Stationary at $1^{\text {st }}$ level \\
\hline LRGDP & 0.1669 & 0.0000 & Stationary at $1^{\text {st }}$ level \\
\hline LRIR & 0.0000 & - & Stationary at level \\
\hline
\end{tabular}

The above unit-root table estimations revealed mixed behavior of stationary comprise level and $1^{\text {st }}$ difference. Based on the above outcomes, it led to the application of ARDL Bounds testing techniques. Pesaran et al. (2001) initiated a new and technique named ARDL Bound Testing method, a relatively new and modern technique, which is co-integration techniques to form or study the long-run relationship between variables.

\subsection{Lag-length Criteria}

Through implying VAR lag order selection criteria, we revealed lag-length 1 through various techniques comprise of AIC and SC.

\begin{tabular}{|c|c|c|}
\hline Lag & AIC* & SC** \\
\hline 0 & -8.325099 & -8.124359 \\
\hline 1 & -19.16731 & -17.96287 \\
\hline 2 & -19.09206 & -16.88392 \\
\hline 3 & -18.64346 & -15.43162 \\
\hline 4 & -18.38881 & -15.43162 \\
\hline *AIC referred to Akaike Info Criterion \\
**SC referred to Schwarz Info Criterion \\
\hline
\end{tabular}


International Journal of Economics, Business and Accounting Research (IJEBAR)

Peer Reviewed - International Journal

Vol-4, Issue-3, 2019 (IJEBAR)

E-ISSN: 2614-1280 P-ISSN 2622-4771

https://jurnal.stie-aas.ac.id/index.php/IJEBAR

\subsection{ARDL Bound Test}

The ARDL bounds test stated that the variables involved in our model are bound together in the longrun period. The following table outcomes revealing robust strong long-run bonding among our model variables. When the F-statistics value (11.43208) exposed more than the lower and upper limit of critical values bounds at a $5 \%$ level of significance.

\begin{tabular}{|c|c|c|}
\hline Test Statistics & Values & $\mathrm{K}$ \\
\hline F-Statistics & 11.43208 & 4 \\
\hline \multicolumn{2}{|c|}{ Critical Values Bounds } \\
\hline Sign. & $\mathrm{I}(0)$ & $\mathrm{I}(1)$ \\
\hline $1 \%$ & 3.74 & 5.06 \\
\hline $5 \%$ & 2.86 & 4.01 \\
\hline $10 \%$ & 2.45 & 3.52 \\
\hline
\end{tabular}

\subsection{ARDL Co-integration Form and Long-run Coefficients}

\section{Co-integration Form}

\begin{tabular}{|l|l|l|l|}
\hline \multicolumn{1}{|c|}{ Variable } & Coefficient & Probability & t-statistics \\
\hline D(M2/LRCPI(-1)) & 0.333591 & 0.0097 & 2.727596 \\
\hline D(LFI) & 0.466281 & 0.0007 & 3.689400 \\
\hline D(LOEXR) & -0.052783 & 0.7671 & -0.298392 \\
\hline D(LRGDP) & -0.180986 & 0.0121 & -2.638419 \\
\hline D(LRIR) & 0.025577 & 0.3191 & 1.009836 \\
\hline CointEq(-1) & -0.287483 & 0.0020 & -3.326342 \\
\hline
\end{tabular}

Under the short-run period, there is a positive and significant relationship between financial innovation and the real money demand while a negative but significant relationship revealing between real gross domestic product and the real money demand in the Malaysian economy throughout 1970-2018.

\begin{tabular}{|l|l|l|l|}
\hline Variable & Coefficient & Probability & t-statistics \\
\hline LFI & -0.342317 & 0.0844 & -1.773639 \\
\hline LOEXR & 0.975405 & 0.0170 & 2.500245 \\
\hline LRGDP & -0.629556 & 0.0000 & -4.767616 \\
\hline LRIR & 0.275845 & 0.1255 & 1.567712 \\
\hline C & 13.073965 & 0.0000 & 10.767811 \\
\hline
\end{tabular}

The CointeEq may be written as;

$$
\text { Real Money Demand }=\frac{\text { LM2 }}{\text { LRCPI }}=13.074-0.342(\text { LFI })+0.975 \text { (LOEXR) }-0.629(\text { LRGDP) }+0.276 \text { (LRIR) }
$$

Under the long-run period, a positive and significant relationship revealed between the official exchange rate and real money demand. It directs that, by increasing a $1 \%$ change in the official exchange rate, the real money demand predicted to increase by 0.9754 units. Whereas there is a negative and significant relationship between real gross domestic product and real money demand. It leads that by an increase in $1 \%$ in real GDP, it predicted that real money demand decrease by 0.6395 units, and lastly real money demand predicted 13.0796 when all independent variable is zero in the Malaysian economy.

\subsection{Diagnostic Test \\ Normality Test through Histogram}


International Journal of Economics, Business and Accounting Research (IJEBAR)

Peer Reviewed - International Journal

Vol-4, Issue-3, 2019 (IJEBAR)

E-ISSN: 2614-1280 P-ISSN 2622-4771

https://jurnal.stie-aas.ac.id/index.php/IJEBAR

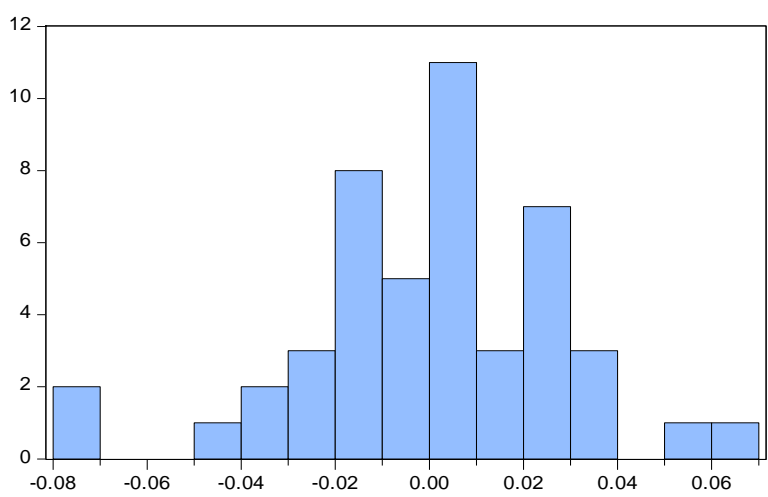

Normality test conducted through histogram which revealed that probability value $(0.0512)$ is more than a $5 \%$ that confirm the normality condition satisfaction.

\section{Serial Correlation Analysis}

To check the problem of serial correlations existence, first, we undertake the null-hypothesis as there is no serial correlation. We implied Breusch-Godfrey serial correlation LM test. The following table revealing the results in which our null-hypothesis is accepted because of Prob. The Chi-square value is more than a $5 \%$.

\begin{tabular}{|l|l|}
\hline \multicolumn{2}{|c|}{ Breusch-Godfrey Serial Correlation - LM Test } \\
\hline Observed $\mathrm{R}^{2}=1.3312$ & Probability Chi-square $(2)=0.5140$ \\
\hline
\end{tabular}

\section{Heteroscedasticity Test}

To check the presence of heteroscedasticity problems in our model, we used the heteroscedasticity test presented by Breusch-Pagan-Godfrey in the following table. The estimation led to non-presence or absence of heteroscedasticity problem.

$$
\begin{array}{|l|l|}
\hline \multicolumn{2}{|c|}{\text { Breusch-Pagan-Godfrey Heteroscedasticity Test }} \\
\hline \text { Observed } R^{2}=15.38413 & \text { Probability Chi-square }(9)=0.0809 \\
\hline
\end{array}
$$

\section{CUSUM Test - Model Fitness Analysis}

CUSUM tests exposed the fitness of the estimated model. If the estimated line (blue line) remained inside the upper and lower limit (both red lines), we can say that our model is robust and fit.
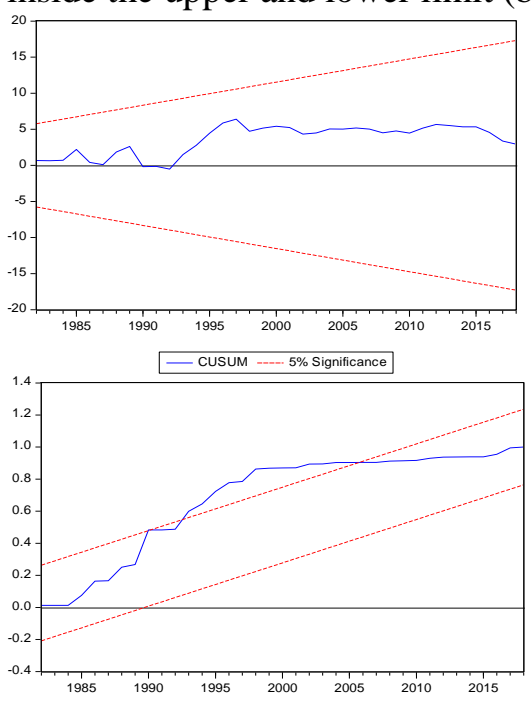
International Journal of Economics, Business and Accounting Research (IJEBAR)

Peer Reviewed - International Journal

Vol-4, Issue-3, 2019 (IJEBAR)

E-ISSN: 2614-1280 P-ISSN 2622-4771

https://jurnal.stie-aas.ac.id/index.php/IJEBAR

\section{Conclusion and Recommendations}

Our research study intended to distinguish the fundamental determinants dynamics for Malaysian money demand function. Through empirical analysis on various economic factors comprise, price level, interest rate, real GDP, and financial innovation as independent variables, we imply various econometric techniques including unit-root, ARDL bound test. We confirm the long-run bounding of all assumed variables through the ARDL bound test. Based on estimations consequences, we accomplish a positive and significant relationship for financial innovation although significant and negative relationships found for real GDP in regards to real money demand function for the Malaysian economy over 1970-2018. It directed to conclusions that financial innovation moves in the same direction with real money demand and its decisive factors while considering real money demand function in Malaysia for a short period. On the other hand, real GDP is also a very imperative factor but its movement with real money demand function in the opposite direction or both having an inverse relationship in the short-run phase in Malaysia. It is concluded that positive significant relationship exposed for the official real exchange rate and negative but significant for real GDP with real money demand for the Malaysian economy over the long-run phase. It means for effective real money demand function over the long-run phase, Malaysian authorities need to engage official real exchange rate as determinant because of when real exchange rate will increase it may cause to increase in real money demand function while real GDP exposed again negative or inverse relationship that direct to if Malaysian authorities decrease real GDP it will make the cause of an increase in real money demand and when real GDP of Malaysia will increase, make the cause of diminishing real money demand function.

\section{ReferenceS}

Achsani, N. A. (2010). Stability of Money Demand in an Emerging Market Economy: An Error Correction and ARDL Model for Indonesia. Research Journal of International Studies, 13, 9.

Ahmad, E., \& Munirs, M. (2000). An Analysis of Money Demand in Pakistan. Pakistan Economic and Social Review, 38(01), 20.

Anwar, S., \& Asghar, N. (2012). Is Demand for Money Stable in Pakistan? Pakistan Economic and Social Review, 50(01), 1-22.

Arango, S., \& Nadiri, MI. (1981). Demand for Money in Open Economies. J. Mon. Econ, 7, 69-83.

Bahmani-Oskooee, M., \& Tanku, A. (2006). Black Market Exchange Rate, Currency Substitution and the Demand for Money in Ldcs (SSRN Scholarly Paper ID 938453). Social Science Research Network. https://papers.ssrn.com/abstract=938453

Bank Negara Malaysia. (2011). Bank Negara Malaysia Annual Report 2011 | Bank Negara Malaysia| Central Bank of Malaysia. https://www.bnm.gov.my/index.php?ch=en_publication\&pg=en_ar\&ac=17

Bara, A., \& Mudzingiri, C. (2016). Financial innovation and economic growth: Evidence from Zimbabwe. Investment Management and Financial Innovations, 13(2), 65-75. https://doi.org/10.21511/imfi.13(2).2016.07

Baumol, W. J. (1952). The transaction s Demand for Cash: An Inventory Approach. Quaterly Journal of Economics, 66, 545-556.

Bitrus, Y. P. (2011). The determinants of the demand for money in developed and developing countries. Journal of Economics and International Finance, 03(15), 08.

Chen, B. (1997). Long-Run Money Demand and Inflation in China. Journal of Macroeconomics, 19(3), 609-617. https://doi.org/10.1016/S0164-0704(97)00032-3 
International Journal of Economics, Business and Accounting Research (IJEBAR)

Peer Reviewed - International Journal

Vol-4, Issue-3, 2019 (IJEBAR)

E-ISSN: 2614-1280 P-ISSN 2622-4771

https://jurnal.stie-aas.ac.id/index.php/IJEBAR

Choudhry, T. (1995). High inflation rates and the long-run money demand function: Evidence from cointegration tests. Journal of Macroeconomics, 17(1), 77-91. https://doi.org/10.1016/01640704(95)80004-2

Darrat, A. F. (1985). The demand for money in a developing economy: The case of Kenya. World Development, 13(10-11), 1163-1170. https://doi.org/10.1016/0305-750X(85)90034-8

GHaffar, A., Roslan, \& Habibullah, M. S. (1987). Price expectations and the demand for money in Malaysia. Journal Ekonomi Malaysia, 15, 2-35.

Hoffman, D. L., Rasche, R. H., \& Tieslau, M. A. (1995). The stability of long-run money demand in five industrial countries. Journal of Monetary Economics, 35(2), 317-339. https://doi.org/10.1016/0304-3932(95)01189-U

Kombo, J. N., \& Nyangoro, O. (2019). Empirical Analysis of Real Money Demand Function in Kenya. Journal of Emerging Issues in Economics, Finance and Banking, 8(1), 17.

Narayan, P. K., Narayan, S., \& Mishra, V. (2009). Estimating money demand functions for South Asian countries. Empirical Economics, 36(3), 685-696. https://doi.org/10.1007/s00181-0080219-9

Noman, A. H. Md., Gee, C. S., \& Isa, C. R. (2017). Does competition improve financial stability of the banking sector in ASEAN countries? An empirical analysis. PLoS ONE, 12(5). https://journals.plos.org/plosone/article?id=10.1371/journal.pone. 0176546

Pesaran, M. H., Shin, Y., \& Smith, R. J. (2001). Bounds testing approaches to the analysis of level relationships. Journal of Applied Econometrics, 16(3), 289-326. https://doi.org/10.1002/jae.616

Rahim, A. (1986). The demand for money in Malaysia. Analisis, 1, 27-40.

Semudram, M. (1981). The demand for money in the Malaysian economy. Malayan Economic Review, 26(2), 53-63.

Sichei, M. M., \& Kamau, A. W. (2012). Demand For Money: Implications for The Conduct of Monetary Policy in Kenya. International Journal of Economics and Finance, 4(8), 10.

Skrabic, B., \& Tomic-Plazibat, N. (2009). Evidence of the Long-run Equilibrium between Money Demand Determinants in Croatia. World Academy of Science, Engineering and Technology, $49,4$.

Tobin, J. (1956). The Interest Elasticity of the Transactions Demand for Cash. Review of Economics and Statistics, 38, 6.

Treichel, V. (1997). Broad Money Demand and Monetary Policy in Tunisia. International Monetary Fund Working Paper, WP/97(22).

Tseng, W., \& Corker, R. (1991). Financial liberalisation, money demand and monetary policy in Asian countries. International Monetary Fund, Occasional Paper, No. 84.

Wihardja, M. M. (2013). Financial Integration Challenges in ASEAN beyond 2015. In Working Papers (DP-2013-27; Working Papers). Economic Research Institute for ASEAN and East Asia (ERIA). https://ideas.repec.org/p/era/wpaper/dp-2013-27.html

Yu, H., \& Gan, P.-T. (2009). An Empirical Analysis of the Money Demand Function in ASEAN-5. International Research Journal of Finance and Economics, 33, 11. 